\title{
Međunarodno iskustvo kao mogući prediktor sklonosti studenata prema emigraciji
}

\author{
Ivona Škreblin Kirbiš*
}

\begin{abstract}
Sažetak
Kroz međunarodna iskustva studenti stječu mnoga znanja $i$ vještine te postaju vrijedan potencijalni resurs za oporavak hrvatskoga gospodarstva. No, pitanje je jesu li zbog svoje veće konkurentnosti i novih pogleda nakon završetka studija skloniji ostati u Hrvatskoj ili tražiti posao u inozemstvu. U radu se na uzorku od 118 studenata ekonomije istražuje sklonost emigraciji te stavovi povezani s emigracijom i prošlo međunarodno iskustvo kao mogući prediktori namjere života i rada u inozemstvu. Rezultati ukazuju na to da je $20 \%$ studenata sklono emigraciji, njih $30 \%$ neodlučno je, a 50\% nije sklono emigraciji. Emigraciji su skloniji studenti koji imaju negativniji opći stav prema Hrvatskoj i koji povoljnijima procjenjuju privlačne čimbenike, odnosno ukupne prilike u inozemstvu. Kada se analiziraju pojedinačni potisno-privlačni čimbenici, rezultati ukazuju na to da je najvažniji prediktor sklonosti emigraciji procjena prilika za posao. Studenti koji prilike za posao doživljavaju povoljnijima u inozemstvu u odnosu na Hrvatsku, koji imaju negativniji opći stav prema Hrvatskoj te imaju bogatije međunarodno iskustvo skloniji su emigraciji. Proizlazi da je iznimno važna strategija zadržavanja mladih visokoobrazovanih s međunarodnim iskustvom upravo kreiranje prilika za posao.
\end{abstract}

Ključne riječi: emigracija, međunarodno iskustvo, potisni čimbenici, privlačni čimbenici

JEL klasifikacija: F22, O15

\section{Uvod}

Trend povećanoga iseljavanja iz Hrvatske zabilježen je od 2009. i početka globalne ekonomske krize te se je nastavio kroz razdoblje ulaska Hrvatske u Europsku uniju 1. srpnja 2013. godine (Župarić-Iljić, 2016, 2). Prema podatcima Državnoga zavoda za statistiku u 2017. godini Hrvatsku je napustilo 47.352 sta-

* Dr. sc. Ivona Škreblin Kirbiš, viši predavač, Zagrebačka škola ekonomije i managementa. Adresa: Jordanovac 110, 10000 Zagreb, Hrvatska. E-adresa: ivona.skreblin@zsem.hr 
novnika (Stolnik, 2018, 1). Pri tom valja imati na umu da je prava slika emigracije nešto drukčija — kombinirajući podatke iz nacionalnih statističkih ureda zemalja Europske unije, naša državna statistika treba se korigirati za 2,6 puta (Draženović et al., 2018, 436). U 2017. godini glavno odredište bilo je Njemačka (64\%), a zatim Austrija (6\%) i Irska (6\%). Među iseljenicima nešto je više muškaraca $(55,4 \%)$ u odnosu na žene, i najviše je onih koji odlaze u najproduktivnijoj radnoj i reproduktivnoj dobi od 20 do 39 godine (48\%) (Stolnik, 2018, 1). Kada govorimo o odljevu mozgova, iako se znanstvenici slažu da ne postoje točne i općeprihvaćene statistike, Adamović i Mežnarić $(2003,146)$ navode da je između 1990. i 2000. Hrvatsku napustilo 68,6\% visoko obrazovanoga stanovništva. Upravo zbog svih tih razloga važno je istražiti namjere odlaska mladih u inozemstvo, kao i njihove motive, te identificirati eventualne prediktore namjere odlaska.

Ulaskom Hrvatske u Europsku uniju otvorile su se također mnogobrojne mogućnosti mobilnosti za hrvatske studente. Na žalost, iako kontinuirano raste, postotak studenata koji su uključeni u neki program međunarodne razmjene u okviru Erasmus + programa na godišnjoj razini još uvijek je izrazito nizak, i za razdoblje 2015. i 2016. godine iznosi samo 1,4\% (Agencija za mobilnost i programe EU, 2017, 45). Prema Hauschildt et al. (2017, 191), postotak studenata iz Hrvatske koji su sudjelovali u nekom obliku iskustva studiranja u inozemstvu iznosi $11 \%$, a za usporedbu taj je postotak najviši u skandinavskim zemljama i kreće se od $28 \%$ do $39 \%$. Najmanji se postotak bilježi u Rumunjskoj (4\%). Kroz međunarodna iskustva studenti stječu konkurentsku prednost na tržištu rada u Hrvatskoj i inozemstvu, ali i postaju vrijedan potencijalni resurs za oporavak hrvatskoga gospodarstva. U spomenutom izvještaju Agencije za mobilnost i programe EU $(2017,68-70)$ stoji da se studenti koji su bili u nekom od programa mobilnosti velikim dijelom slažu da su kroz takav program dodatno razvili svoje kompetencije (primjerice rad u timu, kreativno izražavanje), kako se bolje prilagođavaju i djeluju u novim situacijama i kako bolje poznaju svoje jake i slabe strane, te procjenjuju da imaju bolje buduće izglede za posao. Također, njih čak 90,8\% može se lako zamisliti da rade u inozemstvu u budućnosti. Studentska mobilnost potiče razvoj novih kulturnih, društvenih i akademskih vrijednosti, što na individualnoj i društvenoj razini znači veću toleranciju i borbu protiv diskriminacije. Studenti s međunarodnim iskustvom nositelji su novih ideja i kontakata, što pogoduje razvoju inovacija. Baš zato što su uistinu vrijedan ljudski potencijal važno je pratiti namjere emigracije studenata s međunarodnim iskustvom i istražiti kakav je odnos međunarodnoga iskustva i sklonosti emigraciji.

$\mathrm{U}$ ovom radu ispituju se kvantitativnim istraživanjem namjere života i rada u inozemstvu nakon završetka studija, te stavovi povezani s emigracijom i prošlo međunarodno iskustvo kao mogući prediktori sklonosti emigraciji na uzorku studenata privatne visoke škole. 


\section{Pregled literature}

U 2004. godini čak 75\% studenata razmišlja o odlasku u inozemstvo, a 22,5\% njih sklono je nakon završetka fakulteta profesionalnu karijeru započeti u inozemstvu (Šverko, 2005, 1149). Kolčić et al. (2014, 455) nalaze da je 35\% studenata završne godine medicine spremno na trajnu emigraciju. Prema podatcima Eurobarometra za 2016., u prosjeku 32\% mladih Europljana želi studirati, usavršavati se ili raditi u drugoj europskoj zemlji, a taj postotak vrijedi i na razini Hrvatske (Potočnik i Adamović, 2018, 5). U blagom je porastu broj mladih koji bi otišli na dulje vrijeme i onih koji bi otišli zauvijek. U 2013. godini takvih je bilo ukupno oko $70 \%$, pri čemu ostaje samo oko $15 \%$ mladih koji ne bi otišli ni na dulje vrijeme ni zauvijek i oko $15 \%$ onih koji o tome nisu razmišljali (Potočnik i Adamović, 2018, 6-7). Relja et al. $(2015,16)$ zaključuju da studenti iz Splita i Sarajeva, iako načelno imaju pozitivan stav prema odlasku mladih u inozemstvo na školovanje ili rad, na osobnoj razini njih samo trećina iznosi želju za odlaskom.

U izvještaju Eurostata i Europske komisije navedeno je da su motivi emigracije vrlo slični bez obzira na zemlju porijekla imigranata u Europsku uniju, a oni se odnose uglavnom na ekonomske razloge za muškarce i nešto češce na obiteljske razloge kod žena (Schoorl et al., 2000, 75). Kada govorimo o motivima i razlozima migracije, ne postoji integrirana teorija međunarodne migracije, međutim među poznatijim je teorijama ona potisnih i privlačnih čimbenika, takozvani push-pull model (Lee, 1966, 47-57; Schoorl et al., 2000,3). Prema tom modelu, postoje potisni čimbenici unutar zemlje iz koje osoba emigrira, koji u kombinaciji s privlačnim čimbenicima zemlje u koju osoba imigrira utječu na migraciju. Pri tom treba imati na umu da je u procjeni potisnih i privlačnih čimbenika najvažnija percepcija osobe, odnosno procjena svake pojedine osobe u kojoj mjeri određeni čimbenik smatra nepovoljnim ili povoljnim (Šverko, 2005, 1151).

Koristeći podatke Gallup World Poll, Nikolova i Graham $(2015,1)$ zaključili su da je nezadovoljstvo životom povezano sa željom za emigracijom. Gevrek et al. (2016, 20-21) istražuju varijable koje bi mogle biti u pozadini povezanosti stupnja obrazovanja i sklonosti emigraciji te kao posrednika toga odnosa navode percepciju političke situacije u zemlji. U istraživanju na reprezentativnom uzorku mladih iz Singapura u dobi između 19 i 30 godina, Chan-Hoong i Soon (2011, 50-61) navode da je namjera emigracije pozitivno povezana s društvenim normama koje potiču iseljavanje, percipiranim društvenim statusom onih koji su se iselili, socioekonomskom sigurnošću koju emigracija pruža, samoprocjenom kompetencije za emigracijom te vrijednostima koje promoviraju postignuće i samostalnost. Namjera emigracije negativno je povezana s percipiranom prijetnjom od stranih talenata, osjećajem nacionalnoga ponosa, subjektivnoga blagostanja i snagom obiteljskih veza. U svojem istraživanju Draženović et al. $(2018,437)$ kao važne odrednice emigracije stanovništva iz novih zemalja članica Europske unije, osim pristupa slobodnomu kretanju radne snage, navode karakteristike zemlje podrijetla, ekonomski razvoj, kratkoročne ekonomske indikatore i kvalitetu institucija mjerenu kroz prisutnost korupcije u zemlji podrijetla i zemlji odredišta. 
U Hrvatskoj se također već dulji niz godina istražuju razlozi emigracije. Adamović i Mežnarić $(2003,158)$ ukazuju na to da se prediktorski skup potisnih varijabli koje predviđaju namjeru emigracije mladih znanstvenika svodi na nezadovoljstvo perspektivom u instituciji i mogućnostima za znanstveno usavršavanje i razvoj. Šverko $(2005,1160)$ kao razlog odlaska navodi bolje ekonomske uvjete te bolje mogućnosti školovanja i usavršavanja. Kolčić et al. (2014, 455-456) navode da je sklonost emigraciji studenata medicine povezana s interesom za edukacijske programe u inozemstvu, a uvjerenje o mogućnosti željene specijalizacije u Hrvatskoj negativno je povezano sa sklonošću emigraciji. Relja et al. (2015, 17-18) među razlozima odlaska studenata izdvajaju materijalne i ekonomske razloge kao važnije od onih vezanih za osobni razvoj. Rajković Iveta i Horvatin $(2017,264-268)$ ističu da su glavni motivi iseljavanja mladih u Irsku u obliku potisnih čimbenika ekonomski motivi, psihološko nezadovoljstvo uzrokovano korupcijom i nepotizmom, te u obliku privlačnih čimbenika englesko govorno područje, otvoreno tržište rada, jednostavne birokracijske procedure potrebne za rad i život, dobra prometna povezanost, pozitivna iskustva prijašnjih migranata i mogućnost brzoga pronalaska posla. U kvalitativnom istraživanju Potočnik i Adamović (2018, 26-28) identificiraju razloge za ostanak u Hrvatskoj kao što su zadovoljstvo trenutačnim životom, vezanost uz obitelj, (lokal)patriotizam te percipirane poteškoće pri preseljenju. Identificirani razlozi za odlazak su pak utjecaj prijatelja koji su već otišli u inozemstvo, obrazovanje, zapošljavanje, općenito nezadovoljstvo životom u Hrvatskoj i politički razlozi.

Da je namjera dobar prediktor emigracije, zaključak je nizozemskoga istraživanja usporedbe namjera i ponašanja vezanih uz emigraciju (Van Dalen i Henkens, 2013, 225-241). Autori navode da 34\% onih koji izjavljuju da imaju namjeru emigrirati uistinu emigriraju kroz idućih 5 godina, te zaključuju da su čimbenici povezani s namjerom za emigracijom isti oni koji potiču stvarnu emigraciju, što ukazuje na važnost proučavanja namjera emigracije i prediktora takvih namjera.

U Hrvatskoj se čini nema radova koji na kvantitativni način istražuju odnos između sklonosti emigraciji i prethodno međunarodno iskustvo. Li et al. (1996, 51-67) usporedili su namjere emigracije studenata podrijetlom iz Hong Konga koji su na studijskom boravku u Ujedinjenom Kraljevstvu i studenata koji su u Hong Kongu, te zaključuju da međunarodno iskustvo studiranja ne utječe na buduće planove migracije. Hazen i Alberts $(2006,201)$ istražili su namjere emigracije među stranim studentima u SAD-u i navode da vrlo malo studenata dolazi u SAD na studij s namjerom trajne imigracije. Kvedaraitè et al. (2015, 196-203) istražili su namjere emigracije na reprezentativnom uzorku studenata u Litvi te usporedili studente koji su boravili u inozemstvu zbog posla i one koji su boravili u inozemstvu zbog studija. Pri tom autori ne nalaze korelaciju između zadovoljstva boravkom u inozemstvu i namjere ponovne emigracije u zemlju u kojoj su boravili. 


\section{Hipoteze}

U ovom članku cilj je istražiti namjere života i rada u inozemstvu nakon završetka studija te stavove povezane s emigracijom i prošlo međunarodno iskustvo kao moguće prediktore sklonosti emigraciji. U radu su postavljene tri hipoteze: 1 . Studenti imaju pozitivan stav prema emigraciji. 2. Sklonost emigraciji u pozitivnoj je korelaciji sa procjenom prilika u inozemstvu, u negativnoj korelaciji s općim stavom prema Hrvatskoj i procjenom prilika u Hrvatskoj. 3. Važni prediktori stava prema emigraciji su stav prema Hrvatskoj, potisni i privlačni čimbenici i međunarodno iskustvo.

\section{Metodologija}

\subsection{Ispitanici}

Istraživanje je provedeno na 118 studenata ekonomije privatne visoke škole u Zagrebu prosječne dobi 21 godine starosti i prosjeka ocjena 3,87. Veličina uzorka zadovoljava uvjete potrebne za statističke analize koje se koriste u obradi podataka (Brace et al., 2003, 212) i uzorak je reprezentativan za studente visoke škole gdje je istraživanje provedeno. U Tablici 1 i Tablici 2 prikazana je deskriptivna statistika demografskih varijabli. U uzorku je podjednak broj studenata ženskoga i muškoga spola te studenata svake pojedine godine studija. Većina studenata procjenjuje svoj životni standard kao iznadprosječan, što proizlazi iz činjenice da je istraživanje provedeno na privatnoj obrazovnoj instituciji.

Tablica 1. Deskriptivna statistika spola, godine studija i samoprocjene životnoga standarda

Table 1. Descriptive statistics of sex, year of study and self-assessment of standard of living

\begin{tabular}{|l|l|c|}
\hline Varijabla & Postotak \\
\hline \multirow{2}{*}{ Spol } & Muški & $53 \%$ \\
\cline { 2 - 3 } & Ženski & $47 \%$ \\
\hline \multirow{4}{*}{ Godina studija } & Prva godina & $29 \%$ \\
\cline { 2 - 3 } & Druga godina & $22 \%$ \\
\cline { 2 - 3 } & Treća godina & $28 \%$ \\
\cline { 2 - 3 } & Četvrta godina & $20 \%$ \\
\hline \multirow{2}{*}{$\begin{array}{l}\text { Samoprocjena životnoga } \\
\text { standarda }\end{array}$} & U hrvatskom prosjeku & $33 \%$ \\
\cline { 2 - 3 } & Iznad hrvatskoga prosjeka & $67 \%$ \\
\hline
\end{tabular}

Tablica 2. Deskriptivna statistika dobi i prosjeka ocjena
Table 2.
Descriptive statistics of age and average marks

\begin{tabular}{|l|c|c|c|}
\hline Varijabla & M & SD & Min. - max. \\
\hline Dob & 21,07 & 1,46 & $19-27$ \\
\hline Prosjek ocjena & 3,87 & 0,57 & $2,5-5$ \\
\hline
\end{tabular}




\subsection{Procedura}

Podatci su prikupljani anketom u travnju i svibnju 2018. godine tijekom redovne nastave. Anketa je distribuirana u formatu papir-olovka, a ispunjavanje je trajalo oko 15 minuta. Ispunjavanju su pristupili svi studenti kojima je ona distribuirana, što čini postotak dobivenih odgovora $100 \%$.

\subsection{Anketa}

Anketa je konstruirana za potrebe ovoga istraživanja temeljem saznanja iz literature i sastoji se od originalnih i adaptiranih čestica. Anketom se ispituju namjera emigracije, prošlo međunarodno iskustvo, stavovi povezani s emigracijom (opći stav prema Hrvatskoj te procjena potisnih i privlačnih čimbenika emigracije) i demografske varijable. Demografske karakteristike koje se mjere su spol, dob, prosjek ocjena i životni standard mjeren kroz samoprocjenu. Prikaz ostalih varijabli i čestica iz ankete prikazan je u Tablici 3.

Tablica 3. Prikaz pitanja iz ankete

Table 3. Display of questionnaire

\begin{tabular}{|l|l|c|}
\hline \multicolumn{1}{|c|}{$\begin{array}{c}\text { Varijabla } \\
(\text { min-max })\end{array}$} & \multicolumn{1}{|c|}{ Čestica } & $\begin{array}{c}\text { Cronbach } \\
\text { alfa }^{1}\end{array}$ \\
\hline $\begin{array}{l}\text { Namjera } \\
\text { emigracije } \\
(1-5)\end{array}$ & $\begin{array}{l}\text { 1. Nakon završetka studija planiram tražiti } \\
\text { posao u inozemstvu (1-5) } \\
\text { 2. Želim živjeti i raditi u inozemstvu (1-5) } \\
\text { 3. Želim živjeti i raditi u Hrvatskoj (1-5) }\end{array}$ & 0,82 \\
\hline & $\begin{array}{l}\text { 1. Jeste li tijekom studija bili na studentskoj } \\
\text { razmjeni? DA/NE }\end{array}$ & 0,76 \\
$\begin{array}{l}\text { 2. Koliko često općenito putujete izvan } \\
\text { narodno } \\
\text { iskustvo } \\
(3-6)^{2}\end{array}$ & $\begin{array}{l}\text { Hrvatske? a) nisam nikada putovao/putovala } \\
\text { izvan Hrvatske, b) rjeđe od jednom godišnje, c) } \\
\text { jednom godišnje, d) nekoliko puta godišnje, e) } \\
\text { gotovo svaki mjesec } \\
\text { 3. Koje ste sve zemlje do sada posjetili } \\
\text { (neovisno je li zbog odmora, studijskoga } \\
\text { putovanja ili nekoga trećega razloga)? }\end{array}$ & \\
\hline
\end{tabular}

1 Unutarnja konzistencija odnosi se na pouzdanost, odnosno na nezavisnost mjerenja od nesistematskih izvora pogrešaka. Mjereno Cronbach alfom, prihvatljiva razina pouzdanosti je ona iznad 0,7 (Cortina, 1993, 101).

2 Rezultat na indeksu međunarodne razmjene može se kretati od 3 do 6, pri čemu 3 znači da student nikada nije bio na studentskoj razmjeni, da putuje izvan Hrvatske najviše jednom godišnje i da je do sada posjetio 8 ili manje stranih zemalja, a 6 znači da je student bio na studentskoj razmjeni, da putuje češće od jednom godišnje i da je posjetio 9 ili više stranih zemalja do sada. 


\begin{tabular}{|c|c|c|}
\hline $\begin{array}{l}\text { Stav prema } \\
\text { Hrvatskoj } \\
(1-5)\end{array}$ & $\begin{array}{l}\text { 1. Zadovoljan/na sam životom u Hrvatskoj } \\
(1-5) \\
\text { 2. Mogu ostvariti svoje životne planove bez da } \\
\text { napuštam Hrvatsku (1-5) } \\
\text { 3. Općenito govoreći, Hrvatska je bolja od } \\
\text { većine drugih zemalja (1-5) }\end{array}$ & 0,74 \\
\hline $\begin{array}{l}\text { Potisni i } \\
\text { privlačni } \\
\text { čimbenici } \\
(1-5)\end{array}$ & $\begin{array}{l}\text { 1. Prilike za posao }(1-5) \\
\text { 2. Politička situacija }(1-5) \\
\text { 3. Uvjeti života }(1-5) \\
\text { 4. Životni standard }(1-5) \\
\text { 5. Obrazovni sustav }(1-5) \\
\text { 6. Mogućnosti za profesionalno napredovanje } \\
\text { (1-5) } \\
\text { 7. Mogućnost upoznavanja novih kultura (1-5) } \\
\text { 8. Klima (1-5) } \\
\text { 9. Nacionalna sigurnost (1-5) }\end{array}$ & $0,83 / 0,84$ \\
\hline
\end{tabular}

\section{Rezultati i diskusija}

\subsection{Deskriptivna statistika}

U Tablici 4 prikazana je deskriptivna statistika sklonosti emigraciji. Ispitanici se u najvećoj mjeri slažu s tvrdnjom "Želim živjeti i raditi u Hrvatskoj”, što ukazuje na nisku sklonost emigraciji. U skladu s time, za tvrdnju "Želim živjeti i raditi u inozemstvu" slaganje je mnogo niže i na negativnom dijelu skale, iako blizu sredini skale. ${ }^{3}$ Zanimljivo je da se planovi i želje razlikuju — studenti ne žele u tolikoj mjeri živjeti i raditi u inozemstvu (njih 26\% to želi), ali ipak planiraju tražiti posao u inozemstvu nakon završetka studija (njih čak 34\% to planira). Na kombiniranoj mjeri sklonosti emigracije aritmetička sredina je u blago negativnom dijelu skale. Točnije, 50\% ispitanika nije sklono emigraciji, njih 30\% je neodlučno, a njih $20 \%$ sklono je emigraciji. Ti su rezultati nešto drukčiji od rezultata prikazanih u pregledu literature, gdje se postotak studenata sklonih emigraciji kreće od 23\% do 75\% (Potočnik i Adamović, 2018, 6-7; Relja et al., 2015, 16; Kolčić et al., 2014, 455; Šverko, 2005, 1149). Prva hipoteza, prema kojoj studenti imaju pozitivan stav prema emigraciji nije potvrđena. Jedan od razloga za takav rezultat možda leži u činjenici da je istraživanje provedeno na privatnoj visokoj školi koju karakterizira visoka zapošljivost diplomanata. Svakako je preporuka proširiti istraživanje na druge fakultete raznih struka u državnom i privatnom vlasništvu.

3 Negativnim dijelom skale smatra se svaki rezultat niži od srednje vrijednosti skale koja u ovom slučaju skale od 1 do 5 iznosi 3 , a pozitivnim dijelom skale svaki rezultat viši od srednje vrijednosti. 
Tablica 4. Deskriptivna statistika sklonosti emigraciji

Table 4. Descriptive statistics of emigration tendencies

\begin{tabular}{|l|c|c|c|c|c|c|}
\hline \multicolumn{1}{|c|}{ Varijabla } & $\mathrm{M}$ & $\mathrm{SD}$ & $\begin{array}{c}\text { Min- } \\
\text { max }\end{array}$ & $\begin{array}{c}\text { Ocjene } \\
1 \text { i } 2\end{array}$ & $\begin{array}{c}\text { Ocjene } \\
3 \text { i } 4\end{array}$ & $\begin{array}{c}\text { Ocjena } \\
5\end{array}$ \\
\hline $\begin{array}{l}\text { Nakon završetka } \\
\text { studija planiram } \\
\text { tražiti posao u } \\
\text { inozemstvu. }\end{array}$ & 2,86 & 1,36 & $1-5$ & $46 \%$ & $20 \%$ & $34 \%$ \\
\hline $\begin{array}{l}\text { Želim živjeti i } \\
\text { raditi u Hrvatskoj. }\end{array}$ & 2,73 & 1,36 & $1-5$ & $47 \%$ & $27 \%$ & $26 \%$ \\
\hline $\begin{array}{l}\text { Želim živjeti } \\
\text { i raditi u } \\
\text { inozemstvu. }\end{array}$ & 3,94 & 1,10 & $1-5$ & $9 \%$ & $22 \%$ & $70 \%$ \\
\hline Sklonost emigraciji & 2,55 & 1,10 & $1-5$ & $50 \%$ & $30 \%$ & $20 \%$ \\
\hline
\end{tabular}

U Tablici 5 prikazana je deskriptivna statistika međunarodnoga iskustva. Iz Tablice 5 vidljivo je da uzorak čine studenti koji imaju više međunarodnoga iskustva (15\% ih je bilo na međunarodnoj studentskoj razmjeni) u odnosu na hrvatski prosjek, prema kojem godišnje iskustvo međunarodne razmjene ima samo 1,4\% studenata (Agencija za mobilnost i programe EU, 2017, 45), odnosno 11\% (Hauschildt et al., 2017, 191). Izmjeren veći varijabilitet u međunarodnom iskustvu u ovom je slučaju prednost zbog istraživanja povezanosti međunarodnoga iskustva i sklonosti emigraciji.

Tablica 5. Deskriptivna statistika varijable ponašanja - međunarodno iskustvo

Table 5. Descriptive statisics of behaviour variables-international experience

\begin{tabular}{|l|l|c|c|c|c|}
\hline \multicolumn{2}{|l|}{ Varijabla } & Postotak & M & SD & $\begin{array}{c}\text { Min- } \\
\text { max }\end{array}$ \\
\hline $\begin{array}{l}\text { Iskustvo } \\
\text { studentske } \\
\text { razmjene }\end{array}$ & Da & 15 & & & \\
\cline { 2 - 6 } $\begin{array}{l}\text { Čestina putovanja } \\
\text { izvan Hrvatske }\end{array}$ & $\begin{array}{l}\text { Do jednom } \\
\text { godišnje }\end{array}$ & 23 & & & \\
\cline { 2 - 6 } & $\begin{array}{l}\text { Nekoliko puta } \\
\text { godišnje i češce }\end{array}$ & 77 & & & \\
\hline $\begin{array}{l}\text { Broj posjećenih } \\
\text { zemalja }\end{array}$ & Do 8 zemalja & 48 & & & \\
\cline { 2 - 6 } & 9 i više zemalja & 52 & & & $3-6$ \\
\hline $\begin{array}{l}\text { Međunarodno iskustvo (kombinirana } \\
\text { mjera) }\end{array}$ & & 4,38 & 0,88 & \\
\hline
\end{tabular}

4 Tvrdnja je u kombiniranoj mjeri sklonost emigraciji rekodirana na način da vrijednost 1 postaje 5,2 postaje 4,3 ostaje 3,4 postaje 2 i 5 postaje 1 . 
U Tablici 6 prikazana je deskriptivna statistika mjerenih stavova. Opći stav prema Hrvatskoj ukazuje na blago pozitivan stav prema životu u Hrvatskoj. Studenti u najvećoj mjeri smatraju da mogu ostvariti svoje životne planove bez da napuštaju Hrvatsku, ali su nešto manje zadovoljni životom u Hrvatskoj. Možemo reći da su vrlo podijeljenoga mišljenja oko toga je li Hrvatska bolja od većine drugih zemalja s obzirom na to da je tu rezultat oko same sredine skale, u njezinu blago negativnom dijelu.

Gledamo li potisne čimbenike u Tablici 6, odnosno koliko povoljnima studenti ocjenjuju prilike u Hrvatskoj, općenito su neutralni. Kao najpovoljnije prilike u Hrvatskoj smatraju klimu i nacionalnu sigurnost. Zatim blago povoljnim ocjenjuju uvjete života, prilike za posao, mogućnost profesionalnoga usavršavanja i životni standard. Podijeljenoga su mišljenja oko povoljnosti obrazovnoga sustava, a blago negativno ocjenjuju prilike za upoznavanje novih kultura. Ono što vide daleko najnepovoljnije politička je situacija u Hrvatskoj.

Usmjerimo li se na privlačne čimbenike, odnosno procjenu povoljnosti prilika u zemlji koju studenti smatraju najatraktivnijom za rad i život (a to su kako saznajemo iz otvorenih odgovora najčešće Ujedinjeno Kraljevstvo Velike Britanije i Sjeverne Irske, Njemačka, Švicarska, Austrija i SAD), vidimo da studenti sve čimbenike ocjenjuju pozitivno. Pri tom najpovoljnije ocjenjuju mogućnost upoznavanja novih kultura, mogućnosti za profesionalno napredovanje i prilike za posao, a nešto manje povoljno, iako i dalje u pozitivnom dijelu skale, klimu, nacionalnu sigurnost i političku situaciju.

Analiziramo li pak razliku procjene svakoga pojedinoga čimbenika za $\mathrm{Hr}-$ vatsku u odnosu na procjenu za inozemstvo na način da oduzmemo procjenu potisnih čimbenika od procjene privlačnih čimbenika dobivamo sljedeće podatke. Povoljnost klime i nacionalnu sigurnosti ispitanici doživljavaju povoljnije u Hrvatskoj u odnosu na inozemstvo. Sve ostale čimbenike studenti doživljavaju povoljnijima u inozemstvu, pri čemu najveći nerazmjer studenti vide u povoljnosti političke situacije i prilikama za upoznavanje novih kultura, nešto manji nerazmjer u povoljnosti obrazovnoga sustava, prilikama za profesionalno napredovanje, životnom standardu i prilikama za posao te najmanji nerazmjer vide $\mathrm{u}$ uvjetima života. 
Tablica 6. Deskriptivna statistika varijabli stavova — opći stav prema Hrvatskoj, procjena potisnih i privlačnih čimbenika emigracije $(\mathrm{N}=118)$

Table 6. Descriptive statistics of attitude variables-general attitude toward Croatia, assessment of push - pull factors of emigration $(N=118)$

\begin{tabular}{|l|c|c|c|}
\hline \multicolumn{1}{|c|}{ Varijabla } & M & SD & $\begin{array}{c}\text { Min- } \\
\text { max }\end{array}$ \\
\hline 1. Opći stav prema Hrvatskoj & 3,62 & 0,90 & $1-5$ \\
\hline Zadovoljan sam životom u Hrvatskoj. & 3,89 & 1,00 & $1-5$ \\
\hline $\begin{array}{l}\text { Mogu ostvariti svoje životne planove bez da napuštam } \\
\text { Hrvatsku. }\end{array}$ & 4,03 & 1,17 & $1-5$ \\
\hline $\begin{array}{l}\text { Općenito govoreći, Hrvatska je bolja od većine drugih } \\
\text { zemalja. }\end{array}$ & 2,93 & 1,15 & $1-5$ \\
\hline 2. Potisni čimbenici (procjena za Hrvatsku) & 3,32 & 0,62 & $1-5$ \\
\hline Prilike za posao & 3,35 & 0,89 & $1-5$ \\
\hline Politička situacija & 1,99 & 1,02 & $1-5$ \\
\hline Uvjeti života & 3,48 & 0,93 & $1-5$ \\
\hline Životni standard & 3,20 & 0,93 & $1-5$ \\
\hline Obrazovni sustav & 3,04 & 1,06 & $1-5$ \\
\hline Mogućnosti za profesionalno napredovanje & 3,33 & 0,93 & $1-5$ \\
\hline Mogućnost upoznavanja novih kultura & 2,89 & 1,07 & $1-5$ \\
\hline Klima & 4,47 & 0,70 & $1-5$ \\
\hline Nacionalna sigurnost & 4,14 & 0,84 & $1-5$ \\
\hline 3. Privlačni čimbenici (procjena za stranu zemlju & 3,96 & 0,51 & $1-5$ \\
\hline atraktivnu za rad i život) & & & \\
\hline Prilike za posao & 4,23 & 0,77 & $1-5$ \\
\hline Politička situacija & 3,61 & 0,80 & $1-5$ \\
\hline Uvjeti života & 3,93 & 0,82 & $1-5$ \\
\hline Životni standard & 4,12 & 0,72 & $1-5$ \\
\hline Obrazovni sustav & 4,05 & 0,76 & $1-5$ \\
\hline Mogućnosti za profesionalno napredovanje & 4,29 & 0,70 & $1-5$ \\
\hline Mogućnost upoznavanja novih kultura & 4,42 & 0,71 & $1-5$ \\
\hline Klima & 3,40 & 0,87 & $1-5$ \\
\hline Nacionalna sigurnost & 3,56 & 0,93 & $1-5$ \\
\hline 4. Razlika potisno-privlačnih čimbenika & 0,63 & 0,88 & $-4-4$ \\
\hline Prilike za posao & 0,89 & 1,23 & $-4-4$ \\
\hline Politička situacija & 1,62 & 1,32 & $-4-4$ \\
\hline Uvjeti života & 0,45 & 1,39 & $-4-4$ \\
\hline Životni standard & 0,91 & 1,20 & $-4-4$ \\
\hline Obrazovni sustav & 1,02 & 1,36 & $-4-4$ \\
\hline Mogućnosti za profesionalno napredovanje & 0,97 & 1,23 & $-4-4$ \\
\hline Mogućnost upoznavanja novih kultura & $-1,06,57$ & 1,38 & $-4-4$ \\
\hline Klima & 1,40 & $-4-4$ \\
\hline Nacionalna sigurnost & \\
\hline
\end{tabular}




\subsection{Pearsonovi koeficijenti korelacija među varijablama}

U Tablici 7 prikazani su Pearsonovi koeficijenti korelacija među varijablama. Najjača povezanost s namjerom emigriranja negativan je opći stav prema Hrvatskoj te privlačnost prilika u inozemstvu. Neprivlačnost prilika u Hrvatskoj izgleda manje je povezana sa sklonošću emigraciji. Međunarodno iskustvo uopće nije značajno povezano sa sklonošću emigraciji. Gledamo li pak razliku povoljnosti prilika u inozemstvu u odnosu na Hrvatsku, proizlazi da su skloniji emigraciji prvenstveno studenti koji povoljnije ocjenjuju prilike za posao i mogućnosti za profesionalno napredovanje. Nešto je niža korelacija između sklonosti emigraciji i povoljnosti uvjeta života, životnoga standarda, obrazovnoga sustava i mogućnosti upoznavanja novih kultura. Nema statistički značajne korelacije između razlika u procjeni povoljnosti političke situacije, klime, i nacionalne sigurnosti sa sklonosti emigraciji.

Izostanak povezanosti između međunarodnoga iskustva i namjere emigriranja u skladu je s literaturom (Hazen i Alberts, 2006, 214; Kvedaraite et al., 2015, 196-203). Ipak, s obzirom na podatak iz izvještaja Agencije za mobilnost i programe EU (2017, 69), prema kojem se čak 90,8\% studenata koji su bili u programu mobilnosti lako može zamisliti da rade u inozemstvu u budućnosti, trebalo bi dodatno istražiti taj odnos.

Tablica 7. Korelacije sklonosti emigraciji, međunarodnoga iskustva, općega stava prema Hrvatskoj, potisnih i privlačnih čimbenika, te prosjeka ocjena $^{5}$

Table 7. Correlation between emigration tendencies, international experience, general attitude toward Croatia, push — pull factors and average marks

\begin{tabular}{|l|l|l|l|l|l|l|l|l|l|l|l|l|l|l|l|}
\hline & \multicolumn{1}{|c|}{1} & \multicolumn{1}{|c|}{2} & 3 & 4 & 5 & 6 & 7 & 8 & 9 & 10 & 11 & 12 & 13 & 14 & 15 \\
\hline 1 & 1 & & & & & & & & & & & & & & \\
\hline 2 & 0,10 & 1 & & & & & & & & & & & & & \\
\hline 3 & $-0,46^{* *}$ & 0,08 & 1 & & & & & & & & & & & & \\
\hline 4 & $-0,22^{*}$ & $0,19^{*}$ & $0,51^{* *}$ & 1 & & & & & & & & & & & \\
\hline 5 & $0,34^{* *}$ & 0,11 & $-0,22$ & $-0,20^{*}$ & 1 & & & & & & & & & & \\
\hline 6 & $0,45^{* *}$ & $-0,14$ & $-0,53^{* *}$ & $-0,64^{* *}$ & $0,49^{* *}$ & 1 & & & & & & & & & \\
\hline 7 & 0,16 & 0,03 & $-0,22^{*}$ & $-0,61^{* *}$ & $0,44^{* *}$ & $0,46^{* *}$ & 1 & & & & & & & & \\
\hline 8 & $0,25^{* *}$ & $-0,13$ & $-0,47^{* *}$ & $-0,64^{* *}$ & $0,60^{* *}$ & $0,51^{* *}$ & $0,48^{* *}$ & 1 & & & & & & & \\
\hline 9 & $0,26^{* *}$ & $-0,12$ & $-0,43^{* *}$ & $-0,73^{* *}$ & $0,55^{* *}$ & $0,66^{* *}$ & $0,56^{* *}$ & $0,72^{* *}$ & 1 & & & & & & \\
\hline 10 & $0,24^{*}$ & $-0,01$ & $-0,26^{* *}$ & $-0,56^{* *}$ & $0,52^{* *}$ & $0,47^{* *}$ & $0,39^{* *}$ & $0,51^{* *}$ & $0,57^{* *}$ & 1 & & & & & \\
\hline 11 & $0,31^{* *}$ & $-0,02$ & $-0,37^{* *}$ & $-0,72^{* *}$ & $0,47^{* *}$ & $0,57^{* *}$ & $0,49^{* *}$ & $0,57^{* *}$ & $0,69^{* *}$ & $0,51^{* *}$ & 1 & & & & \\
\hline 12 & $0,28^{* *}$ & 0,07 & $-0,26^{* *}$ & $-0,53^{* *}$ & $0,46^{* *}$ & $0,46^{* *}$ & $0,30^{* *}$ & $0,39^{* *}$ & $0,51^{* *}$ & $0,50^{* *}$ & $0,57^{* *}$ & 1 & & & \\
\hline 13 & 0,11 & $-0,02$ & $-0,13$ & $-0,25^{* *}$ & $0,31^{* *}$ & 0,13 & $0,19^{*}$ & $0,23^{* *}$ & 0,05 & 0,05 & $0,19^{*}$ & 0,00 & 1 & & \\
\hline 14 & 0,10 & $-0,12$ & $-0,31^{* *}$ & $-0,36^{* *}$ & $0,55^{* *}$ & $0,27^{* *}$ & $0,34^{* *}$ & $0,47^{* *}$ & $0,35^{* *}$ & $0,22^{*}$ & $0,27^{* *}$ & 0,13 & $0,41^{* *}$ & 1 & \\
\hline 15 & 0,11 & $0,26^{*}$ & 0,06 & 0,09 & $0,21^{*}$ & 0,02 & $-0,05$ & 0,04 & $-0,03$ & 0,16 & $-0,00$ & 0,07 & 0,04 & 0,06 & 1 \\
\hline
\end{tabular}

${ }^{*} \mathrm{p}<0,05, * * \mathrm{p}<0,01$

5 Značenja brojeva u prvom redu i prvom stupcu u sljedeća: Sklonost emigraciji (1); Međunarodno iskustvo (2); Opći stav prema hrvatskoj (3); Potisni čimbenici (4); Privlačni čimbenici (5); Razlika — prilike za posao (6); Razlika — politička situacija (7); Razlika — uvjeti života (8); Razlika — životni standard (9); Razlika — obrazovni sustav (10); Razlika — mogućnosti za profesionalno napredovanje (11); Razlika — mogućnost upoznavanja novih kultura (12); Razlika — klima (13); Razlika — nacionalna sigurnost (14); Prosjek ocjena (15). 


\subsection{Predvidanje sklonosti emigraciji}

U Tablici 8 prikazani su rezultati postepene višestruke linearne regresije predviđanja sklonosti emigraciji temeljem međunarodnoga iskustva, općega stava prema Hrvatskoj, potisnih i privlačnih čimbenika te demografskih varijabli. Skloniji emigraciji su oni studenti koji imaju negativniji opći stav prema Hrvatskoj, a ujedno procjenjuju povoljnima prilike u zemljama koje smatraju atraktivnima za život i rad, pri čemu ti prediktori objašnjavaju $28 \%$ varijance sklonosti emigraciji. Potisni čimbenici nisu značajan prediktor, kao ni međunarodno iskustvo i demografske varijable.

Tablica 8. Predviđanje sklonosti emigraciji temeljem međunarodnoga iskustva, općega stava prema Hrvatskoj, potisnih i privlačnih čimbenika te demografskih varijabli

Table 8. Predicting emigration tendencies based on international experience, general attitude toward Croatia, push — pull factors and demographic variables

\begin{tabular}{|l|l|l|}
\hline \multicolumn{2}{|l|}{ Prediktori } & Beta ponder \\
\hline Važni prediktori & Opći stav prema Hrvatskoj & $-0,45^{* * *}$ \\
\cline { 2 - 3 } & Privlačni čimbenici & $0,23^{*}$ \\
\hline \multirow{4}{*}{ Izostavljeni prediktori } & Međunarodno iskustvo & 0,13 \\
\cline { 2 - 3 } & Potisni čimbenici & 0,05 \\
\cline { 2 - 3 } & Spol & 0,07 \\
\cline { 2 - 3 } & Dob & $-0,09$ \\
\cline { 2 - 3 } & Prosjek ocjena & 0,01 \\
\hline & Samoprocjena životnoga standarda & 0,06 \\
\hline Ukupni korigirani R2 $=0,28, \mathrm{~F}=17,02^{* * *}(\mathrm{df}=82)$ & \\
\hline
\end{tabular}

$* \mathrm{p}<0,05, * * \mathrm{p}<0,01,{ }^{* * *} \mathrm{p}<0,001$

Kako bismo utvrdili koji pojedinačni potisno-privlačni čimbenici predviđaju sklonost emigraciji, provedena je postepena višestruka linearna regresija predviđanja sklonosti emigraciji temeljem međunarodnoga iskustva, općega stava prema Hrvatskoj, razlike između pojedinačnih potisnih i privlačnih čimbenika te demografskih varijabli (Tablica 9). Studenti koji prilike za posao doživljavaju povoljnijima u inozemstvu u odnosu na Hrvatsku, te istovremeno imaju negativniji opći stav prema Hrvatskoj i bogatije međunarodno iskustvo, skloniji su emigraciji, pri čemu ti prediktori objašnjavaju $32 \%$ varijance sklonosti emigraciji. Svi drugi mjereni potisno-privlačni čimbenici nisu se pokazali kao značajni prediktori sklonosti emigraciji, iz čega proizlazi da iznimno važna strategija zadržavanja mladih visokoobrazovanih s međunarodnim iskustvom može biti upravo kreiranje prilika za posao. 
Tablica 9. Predviđanje sklonosti emigraciji temeljem međunarodnoga iskustva, općega stava prema Hrvatskoj, razlike između pojedinačnih potisnih i privlačnih čimbenika te demografskih varijabli

Table 9. Predicting emigration tendencies based on international experience, general attitude toward Croatia, differences between individual push-pull factors and demographic variables

\begin{tabular}{|l|l|l|}
\hline Prediktori & Beta ponder \\
\hline \multirow{4}{*}{ Važni prediktori } & Prilike za posao - razlika & $0,36^{* *}$ \\
\cline { 2 - 3 } & Opći stav prema Hrvatskoj & $-0,30^{* *}$ \\
\cline { 2 - 3 } $\begin{array}{l}\text { Izostavljeni } \\
\text { prediktori }\end{array}$ & Međunarodno iskustvo & $0,21^{*}$ \\
\hline & Politička situacija & $-0,05$ \\
\cline { 2 - 3 } & Uvjeti života & $-0,09$ \\
\cline { 2 - 3 } & Životni standard & $-0,09$ \\
\cline { 2 - 3 } & Obrazovni sustav & $-0,01$ \\
\cline { 2 - 3 } & $\begin{array}{l}\text { Mogućnost profesionalnoga } \\
\text { napredovanja }\end{array}$ & 0,07 \\
\cline { 2 - 3 } & Mogućnost upoznavanja novih kultura & 0,03 \\
\cline { 2 - 3 } & Klima & 0,13 \\
\cline { 2 - 3 } & Nacionalna sigurnost & $-0,07$ \\
\cline { 2 - 3 } & Spol & 0,14 \\
\cline { 2 - 3 } & Prosjek ocjena & 0,06 \\
\cline { 2 - 3 } & Samoprocjena životnoga standarda & 0,06 \\
\hline \multirow{5}{*}{ Ukupni korigirani } & R2 =0,32, F = 15,14*** (df =90) & \\
\hline
\end{tabular}

Ograničenja istraživanja vezana su prvenstveno uz uzorak na kojem je istraživanje provedeno, te ovo istraživanje treba tretirati kao vrijedno preliminarno istraživanje, koje bi bilo korisno proširiti na uzorak s više fakulteta različitih struka, i to privatnih i državnih. Takva saznanja omogućila bi kreiranje politika koje imaju za cilj zadržavanje mladih visokoobrazovanih s međunarodnim iskustvom u Hrvatskoj. Također, bilo bi poželjno pratiti stavove longitudinalno na istim ispitanicima kroz neki vremenski period. Na taj način mogla bi se pratiti promjena stavova prema emigraciji i namjera emigracije, osobito u funkciji međunarodnoga iskustva, s obzirom da neki studenti (prvenstveno oni na nižim godinama studija) još nisu bili na studentskoj razmjeni. 


\section{Zaključak}

Rezultati provedenoga istraživanja ukazuju na to da je $20 \%$ studenata sklono emigraciji, njih 30\% neodlučno, a 50\% nije sklono emigraciji. Njihovi planovi i želje razlikuju se - studenti ne žele u tolikoj mjeri živjeti i raditi u inozemstvu (njih 26\% to želi), gdje ipak planiraju tražiti posao nakon završetka studija (njih $34 \%$ to planira). Jedan od razloga za niži postotak studenata sklonih emigraciji od onoga koji nalazimo u literaturi možda leži u činjenici da je istraživanje provedeno na privatnoj visokoj školi koju karakterizira visoka zapošljivost diplomanata.

Opći stav studenata prema Hrvatskoj blago je pozitivan, a pokazuje se kao značajan i važan prediktor sklonosti emigraciji uz privlačne čimbenike. Svakako je važno razumjeti što je to u pozadini njihova (ne)zadovoljstva životom u Hrvatskoj, percepcije (ne)mogućnosti ostvarenja životnih planova u Hrvatskoj i usporedbe Hrvatske s drugim zemljama. Dio odgovora proizlazi iz analize potisno-privlačnih čimbenika, koja ukazuje na to da studenti, osim klime i nacionalne sigurnosti, sve ostale čimbenike doživljavaju povoljnijima u inozemstvu. Najpovoljnije u inozemstvu u odnosu na Hrvatsku vide političku situaciju i prilike za upoznavanje novih kultura, zatim redom obrazovni sustav, prilike za profesionalno napredovanje, životni standard, prilike za posao i na kraju povoljnost uvjeta života. Važno je istaknuti da potisno-privlačni čimbenik koji u najvećoj mjeri korelira sa sklonošću emigraciji nije onaj koji studenti ocjenjuju najnepovoljnijim, nego su to prilike za posao.

Važnost procjene povoljnosti prilika za posao za sklonost emigraciji očituje se i u rezultatima predviđanja sklonosti emigraciji pojedinačnim potisno-privlačnim čimbenicima. Tada je procjena povoljnosti prilika za posao najvažniji prediktor sklonosti emigraciji. Studenti koji prilike za posao doživljavaju povoljnijima u inozemstvu u odnosu na Hrvatsku, koji imaju negativniji opći stav prema Hrvatskoj i bogatije međunarodno iskustvo skloniji su emigraciji. Pri tom je važna nova spoznaja činjenica da je međunarodno iskustvo također jedan od značajnih prediktora sklonosti emigraciji. Time se otvaraju pitanja o tom kako zadržati u domovini, ili potaknuti na vraćanje u domovinu, mlade visokoobrazovane pojedince s vrijednim znanjima i vještinama stečenim kroz međunarodna iskustva. Poželjno je dodatno istraživati povezanost međunarodnoga iskustva i sklonosti emigraciji kroz proširenje uzorka na studente raznih fakulteta u privatnom i državnom vlasništvu, te pratiti iste ispitanike longitudinalno. Ono što za sada možemo zaključiti jest sljedeće: Kako bi Hrvatska zadržala vrijedan ljudski potencijal mladih visokoobrazovanih s međunarodnim iskustvom, koji mogu biti nosioci novih ideja i pokretači pozitivnih promjena u društvu, moguće je krenuti s kreiranjem prilika za posao koje će biti atraktivne upravo takvim mladim stručnjacima. 


\section{Literatura:}

Adamović, Mirjana; Mežnarić, Silva (2003). Potencijalni i stvarni “odljev” znanstvenog podmlatka iz Hrvatske: empirijsko istraživanje. Revija za sociologiju, 34(3-4), 143-160.

Agencija za mobilnost i programe EU (2017). Rezultati analize izvješća sudionika mobilnosti — Erasmus + Ključna aktivnost 1. URL: http://www.mobilnost.hr/cms_files/2017/12/1513240330_izvjestaj-analiza-izvjesca-sudionika-mobilnosti-za-objavu. pdf (13.04.2019.)

Brace, Nicola; Kemp, Richard; Snelgar, Rosemary (22003). SPSS for Psychologists: A Guide to Data Analysis Using SPSS for Windows. Mahwah: Lawrence Erlbaum Associates.

Chan-Hoong, Leong; Soon, Debbie (2011). A Study on Emigration Attitudes of Young Singaporeans (2010). Institute of Policy Studies. URL: https://kyspp.nus.edu.sg/docs/ default-source/ips/wp19_v2.pdf?sfvrsn=45b89e0b_2 (13.04.2019.)

Cortina, Jose M. (1993). What is Coefficient Alpha? An Examination of Theory and Applications. Journal of Applied Psychology, 78(1), 98.

Draženović, Ivana; Kunovac, Marina; Pripužić, Dominik (2018). Dynamics and Determinants of Emigration: The Case of Croatia and the Experience of New EU Member States. Public Sector Economics, 42(4), 415-447.

Gevrek, Z. Eylem; Kunt, Pinar; Ursprung, Heinrich W. (2016). Education and Emigration Intentions: Evidence from a Natural Experiment in Turkey. URL: https://editorialexpress.com/cgi-bin/conference/download.cgi?db_name=EEAESEM2017\&paper_ $\mathrm{id}=150(13.04 .2019$.)

Hazen, Helen D.; Alberts, Heike C. (2006). Visitors or Immigrants? International Students in the United States. Population, Space and Place, 12(3), 201-216.

Kolčić, Ivana; Čikeš, Mmihaela; Boban, Kristina; Bućan, Jasna; Likić, Robert; Ćurić, Goran; ogaš, Zoran; Polašek, Ozren (2014). Emigration-related Attitudes of the Final Year Medical Students in Croatia: A Cross-sectional Study at the Dawn of the EU Accession. Croatian Medical Journal, 55(5), 452-458.

Kvedaraitė, Nida; Bakšys, Donatas; Repečkienė, Aušra; Glinskienė, Rasa (2015). Research of Experience of Emigration for Employment and Education Purposes of Students. Engineering Economics, 26(1), 196-203.

Lee, Everett S. (1966). A Theory of Migration. Demography, 3, 47-57.

Li, F. L. N.; Findlay, Allan M.; Jowett, A. J.; Skeldon, Ronald (1996). Migrating to Learn and Learning to Migrate: A Study of the Experiences and Intentions of International Student Migrants. International Journal of Population Geography, 2(1), 51-67.

Nikolova, Milena; Graham, Carol (2015). Well-being and Migration Intentions: New Evidence from the Gallup World Poll. Working Paper. URL: http://conference.iza.org/ conference_files/transatlantic_2015/nikolova_m9715.pdf (13.04.2019.)

Potočnik, Dunja; Adamović, Mirjana (2018). Iskustvo migracije i planirani odlasci mladih $i z$ Hrvatske. Zagreb: Friedrich Ebert.

Rajković Iveta, Marijeta; Horvatin, Tea (2017). Suvremeno iseljavanje iz Hrvatske u Irsku s posebnim osvrtom na mlade iz Slavonije. Migracijske i etničke teme, 33(3), 247-274.

Relja, Renata; Reić, Ina; Čerenić, Vanja (2015). Potrebe, mogućnosti i namjera odlaska u inozemstvo: Analiza stavova studenata iz Splita (RH) i Sarajeva (BIH). Andragoški glasnik, 19(1-2), 1-21.

Schoorl, Jeannette; Heering, Liesbeth; Esveldt, Ingrid; Groenewold, George; Erf, Rob van der; Bosch, Alinda; Valk, Helga de; Bruijn, Bart de (2000). Push and Pull Factors of International Migration: A Comparative Report. Luxembourg: European Communities. 
Stolnik, Grozdana (ur.) (2018). Migracija stanovništva Republike Hrvatske u 2017. Priopćenje: Državni zavod za statistiku, 55(7.1.2). URL: https://www.dzs.hr/Hrv_Eng/publication/2018/07-01-02_01_2018.htm (13.04.2019.)

Šverko, Iva (2005). Studentske namjere odlaska u inozemstvo: veličina potencijalnog "odljeva mozgova" i njegove odrednice u 1995., 1997. i 2004. godini. Društvena istraživanja, 14(6), 1149-1174.

Van Dalen, Hendrik P.; Henkens, Kène (2013). Explaining Emigration Intentions and Behaviour in the Netherlands, 2005-10. Population Studies, 67(2), 225-241.

Župarić-Iljić, Drago (2016). Iseljavanje iz Republike Hrvatske nakon ulaska u Europsku uniju. Zagreb: Friedrich Ebert Stiftung.

International Experience as a Possible Predictor of Students' Emigration Tendencies

Ivona Škreblin Kirbiš*

\section{Summary}

Through international experience students acquire new knowledge and skills, thus becoming a valuable potential resource for the recovery of the Croatian economy. However, it is not clear whether, after having completed their studies, their greater competitiveness and new perspectives generate a greater tendency to stay in Croatia or to look for a job abroad. In this paper, on a sample of 118 students who study economics, we investigate emigration tendencies and attitudes related to them as well as international experience as possible predictors of emigration tendencies. Results reveal that $20 \%$ of students indicate a tendency to emigrate, $30 \%$ are undecided and $50 \%$ do not indicate a tendency to emigrate. Students who hold a more negative general attitude towards Croatia and who perceive the total circumstances in a foreign country (pull factors) to be more attractive, are more willing to emigrate. When predicting emigration tendencies with individual push-pull factors, results indicate that the strongest predictor is job opportunities. Students who assess job opportunities as being more attractive abroad than in Croatia, who hold a more negative attitude towards Croatia and who have more international experience are more willing to emigrate. Therefore, an important strategy for keeping young highly skilled people with international experience is by creating job opportunities for them.

Key words: emigration, international experience, pull factors, push factors

JEL classification: F22, O15

* Ivona Škreblin Kirbiš, Ph.D., Senior Lecturer, Zagreb School of Economics and Management. Address: Jordanovac 110, 10000 Zagreb, Croatia. E-mail: ivona.skreblin@zsem.hr 